\title{
3 \\ The dynamics of transition in ownership structure
}

Fan Gang

Much research has shown how and why the non-state sector has been growing in China and the contribution it has made to the overall growth and development of the market system. Other research focuses on the problems of state-owned enterprises (SOEs) and how they should be further reformed.

However, one aspect of the reform process seems to have not yet been fully explored in discussions about the economic transition in China: how the growth of the non-state sector has changed the conditions for the reform of SOEs in particular, and the state sector in general, and why it is necessary to reform SOEs if we want continued growth in the non-state sectors and the economy as a whole. These questions are crucial to an understanding of the current situation in China and the future of China's economic transition and development.

This chapter provides an analysis of the dynamics of incremental reform with special respect to the relationship between the growth of the non-state sector, the change of the ownership structure of the economy as a whole and the reform process of the state sector. ${ }^{1}$

\section{Ownership structure and institutional transition}

The key characteristic of the gradual approach to transition is not the slowness of transition, but that it starts with the development of elements of the new system, such as private sector and market pricing, while keeping the old system, such as SOEs and state banks, unchanged. In comparison, radical reform (as in Russia) started with the reform of the old system, where the new elements started to grow on the ruins of the old structures. Comparisons do not include any value judgments.

One way or another, both approaches to transition require a change of economic structure. The fundamental structure of the economy is the ownership structure. Institutional transition from a planned economy to a market economy requires 


\section{The dynamics of transition in China}

structural changes from the domination of the state-owned sector to that of private (non-state) ownership.

\section{The most important issue for transition: developing the non- state sector}

We define the following ratio as the ownership structure $(/)$ of an economy in transition

$$
J_{0}=\frac{S_{0}}{N_{0}}
$$

where $S$ stands for the state sector, $N$ the non-state sector, subscript indicates the time and $O$ here refers to the initial state.

The institutional transformation can be defined by the change of $J$ from somewhere close to one to somewhere close to zero. This process can be done by the privatisation of $S$ into $N$, but can also be done by simply developing $N$ without changing $S$ in the long run.

Let $\mathrm{g}^{\mathrm{S}}$ and $\mathrm{g}^{\mathrm{n}}$ be the growth rates of state sector and non-state sector respectively. By assuming that the new system, the non-state sector, is more efficient than the old state sector, we have $g^{s}<g^{n}$. We may call this inequality the fundamental presumption of reform, because otherwise the reform is not economically rational. Under such a presumption, if the period of time is long enough, that is, $t \rightarrow \infty$ we have

$$
J=\frac{S_{0}\left(1+g^{s}\right)^{t}}{N_{0}\left(1+g^{n}\right)^{t}}=J 0_{\left(1+g^{n}\right)^{t}} \underset{t \rightarrow \infty}{\longrightarrow} 0
$$

This means that no matter how big the state sector was at the beginning of the transition, or is at any point of time, as long as the non-state sector can grow, the transition will succeed in the long run, simply by the assumption that $g^{s}<\mathrm{g}^{\mathrm{n}}$.

Here we can see that first and foremost the whole process of transition is to allow growth to begin in the non-state sector. Everything starts from there, no matter which reform approach is taken. Mass privatisation may be the way to start growth in the private sector.

\section{The possibility of transition without SOE reform}

We can also see that transition, indicated by the diminishing $J$, may take place without any reform of the state sector. This is justified by the feasibility of the gradual approach, which starts the transition with an initially unreformed state sector. Theoretically, as long as the non-state sector is growing, the position of the state sector will, in the long run, shrink to zero. In a more real sense, for a period of one generation it is feasible that SOEs may operate as before and the state employees may be paid just as before, until they all retire. In the period of one generation, the state sector may disappear and the transition may be completed. 


\section{Dilemmas of China's growth in the Twenty-First Century}

This seems to be the least painful process and an ideal program.

Of course, such a picture looks unrealistic. But it does reveal the key elements of the economic transition: developing the private sector and limiting the expansion of the state sector. No matter how big the state sector is and how big its problems at the moment or at any time in its history, it will be unimportant as long as the private sector is able to grow. The focus of attention should always be on the growth of new institutions. As long as the structure of the economy continues to change, problems can eventually be solved in a comparatively painless fashion.

In China transition started with the growth of the non-state sector that made the $J$ value change from more than 9 in 1979 , to 0.3 in 1998 in terms of the valueadded industrial output (Figure 3.1). The most important achievement of China's economic transition in the past 20 years is the development of the non-state sector. Meanwhile, reform of the state sector has only begun recently. During the 20-year course of transition, the state sector also grew in absolute terms. At the same time, its problems became more severe, including lower profitability, more loss-making enterprises and huge non-performing loans owed to the state banks. All the difficulties of the economy are related to the problems of the state sector. But the reason that the economy continues to grow and the overall situation of financial and social stability is still manageable is simply because the importance of the state sector is diminishing, as it only contributes about 30 per cent of national income.

In a more extreme example of the no-reform transition, in some coastal regions where the non-state sector already accounts for over 90 per cent of economic activities, people do not even bother to reform the SOEs. They simply leave SOEs alone and continue to pay them subsidies. We call this the simple transition or noreform approach to transition.

In general, this may not actually be possible because the state sector does not give up. Interest groups in the state sector do their best to protect themselves and use their political monopoly to get more resources in order to expand and resist shrinkage. They will try all available means to stop the growth of the private sector. Thus, while the no-reform approach is theoretically feasible, it is impossible from the point of view of real-life political economy.

\section{Development of the non-state sector}

\section{Changes of conditions for SOE reform}

A more realistic possibility in the practice of reform, is that the conditions for the reform of SOEs will be improved because of growth in the non-state sector for following reasons.

- Growing competition by the non-state sectors breaks down the 
The dynamics of transition in China

\section{Figure 3.1 Political economy dynamics of China's transition}

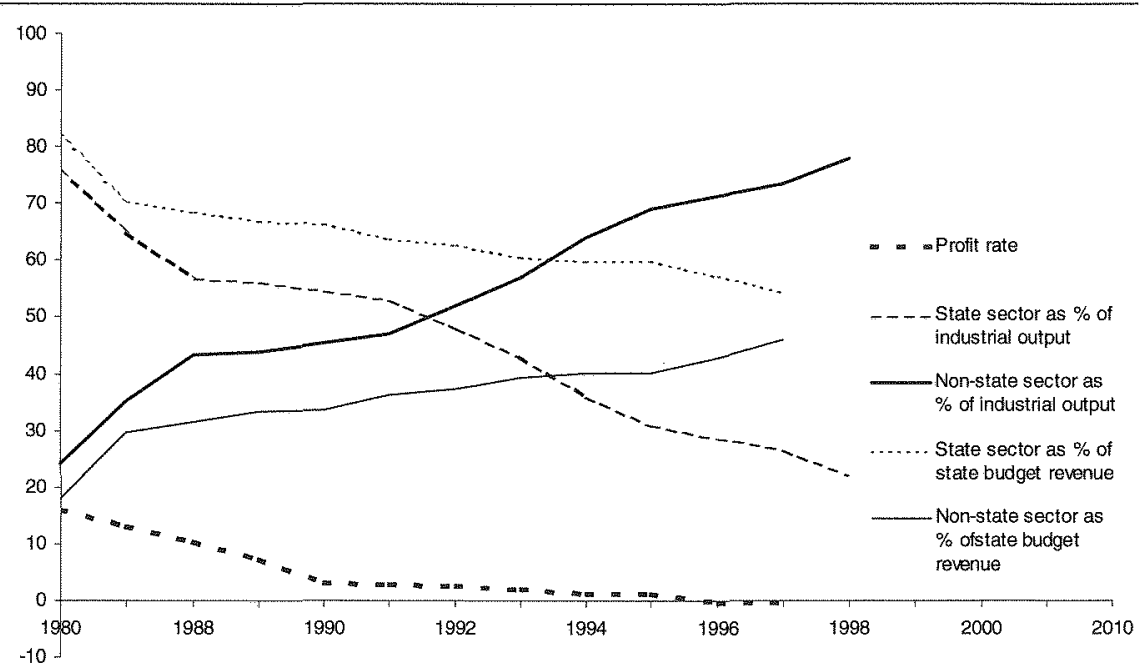

monopoly position of SOEs and pulls down their monopolistic profits. The worsening financial situation is actually the ultimate driving force for the reform program. In real life, reform only takes place when there is no other alternative for survival.

- The development of the non-state sector supports the growth of the economy as a whole and, therefore, provides more job opportunities to absorb laidoff state employees, and/or it makes it possible for the government to mobilise resources to subsidise unemployment compensation for laid-off workers. The higher the share of the non-state sector, the more lay-offs can take place in accordance with regional experiences.

- Growing private financial assets make the capital restructuring and privatisation of SOEs through market mechanism possible.

- The growing entrepreneurial capability of the private sector makes it possible for the remaining assets of SOEs to be taken over for more productive and efficient uses, rather than simply being wrecked in nonproductive hands.

For these reasons, small-sized SOEs are the first to have been reformed. While non-state business is still mostly small, they increase competition mainly against the small SOEs, while they are only at the stage of being able to take over SOEs that are not too big or too complicated in terms of both capital and management. Some preliminary data from the provinces shows that in some regions over 70 per cent of small, local SOEs have already been privatised or reformed in one way or another.

According to the same logic of dynamism, the conditions for reforming the 


\section{Dilemmas of China's growth in the Twenty-First Century}

bigger SOEs should be ready, sooner or later, along with further growth of the non-state sectors. This is the basis of the so-called step-by-step of the incremental transition, and is different from the step-by-step in the theory of sequencing. As long as the development of the non-state sector continues, large SOEs will be reformed, even though doubts exist among those who hold a static vision.

It would be an ideally smooth transition if things progressed this way. In drawing an analogy, it seems a 'West Germany' has been growing and taking over 'Eastern Germany' in China. Such an analogy is drawn because the German transition can be seen as the smoothest among the Eastern European economies, even though the Germans still think their course has been very costly.

\section{The political economy of the government's reform policy}

In many cases, the way of reform depends very much on the political willingness of the government. But it is arguable that such a political willingness is in reality, determined by the economic conditions.

Figure 3.1 also shows that all the major break-through(s) in the policies of SOE reform were only adopted after turning points changed the structure of the economy, that is, the $\mathrm{J}_{\mathrm{t}}$, or the performance of the different sectors relating to the $\mathrm{J}_{\mathrm{t}}$. For example, the Central Committee of the Chinese Communist Party (CCP) wrote into its Reform Decisions, the restructuring of property rights for the first time in 1993. It happened in that year as the $J_{t}$ reached one for the first time, meaning that the non-state sector surpassed the state sector in terms of the proportion of the industrial value-added output. Another example occurred between 1996-97. The SOEs as a whole registered a net loss in the first half of 1996 and 1997. The CCP then adopted a new reform decision at its Fifteenth Party Congress, announcing that the non-state sector should have equal legal status with the SOEs and that small SOEs should be fully subject to market competition, even if this meant their privatisation. In many coastal regions, the government reform policy changed sharply when the private sector surpassed the state sector as the main source of local fiscal revenue. Nothing was accidental about this process.

Theoretically, government policy depends on how much it stands to gain from reform and how much it stands to lose if it reforms. The most important thing here is that all of the factors relating to policymaking are the variables of the $\mathrm{J}_{\mathrm{t}}$, and therefore, that the policy itself is a dependent variable of the $J_{t}$. Such a correlation may be summarised in the following simplified model.

Suppose a local government can make its own reform policies on its own economic calculation. Its basic behavioural model can be written as

$\mathrm{z}^{\mathrm{n}}\left(\mathrm{J}_{\mathrm{t}}\right) \geq \mathrm{z}^{\mathrm{s}}\left(\mathrm{J}_{\mathrm{t}}\right)$

where $z^{s}\left(J_{t}\right)=$ that which the government receives if not reforming SOEs

all kinds of Government revenues provided by the SOEs concerned (profits, 


\section{The dynamics of transition in China}

taxes , plus any 'off-budget revenues')

+ wage income generated by the SOEs for the employees $\left(U_{\mathrm{r}}\right)$

- fiscal subsidies to SOEs $\left(J_{5}\right)$

- non-performing loans owed by SOEs to the state banks $\left(J_{t}\right)$

- all the troubles of dealing with SOEs' debts and unemployment and daily operations $\left(J_{t}\right)$

And $z^{n}(J)=$ if the government goes with reforms

all kinds of government revenues from the non-state companies concerned $\left(J_{\tau}\right)$

+ proceeds from privatisation $\left(\mathrm{J}_{\mathrm{t}}\right)$

+ wage income provided by the non-state undertakings $\left(\mathrm{J}_{t}\right)$

- expenditures for clearing up the debts of SOEs $\left(J_{t}\right)$

- expenditures on unemployment compensation due to the lay-off of state employees $\left(J_{t}\right)$

- premium of the political risks that reform may be faced with $\left(J_{t}\right)$.

Theoretically, the government will choose to 'reform' when the inequality holds and choose to stay with 'no change' if it does not.

It can be demonstrated in detail that the components of both sides of the inequality are somehow variables of $J_{\tau}$ and so, the inequality changes with changes to the $J_{t}$. This explains the evolution of the government policy - from a planning economy dominated by state ownership, to the recent market economy with diversified investors and mixed ownership.

Some may argue for the reversed causality. That is, it seems that it was the (previous) government policies that led to the change of economic structure, rather than vice versa. In some sense, causality may not be important as long as the correlation is clear. But the time lag between the development of reality and the progress of policies does hint at the causal relationship. Since the early 1990, China's reforms, particularly SOE reforms, have featured the bottom-up and crisis push processes, and most reforms were actually initiated by local people and local enterprises. In most cases and at all levels, the government has failed to take the lead but instead has been waiting until the conditions (determined by $J_{r}$ ) change making the situation clearer and more favorable.

\section{The dynamics of the political economy of 'lay-off'}

More than 100 million state employees used to enjoy life-time employment and the many privileges offered by the government. Although the SOEs were 20-30 per cent over-staffed, even according to the government's official estimation, the lay-off (particularly the mass lay-off of millions of people per year) was unthinkable even five years ago. But since 1995, over 15 million state employees have been laid off at an accelerated rate. It has become so common that almost every SOE has laid off employees. 


\section{Dilemmas of China's growth in the Twenty-First Century}

The question is, why have state employees, who are perhaps the most powerful interest group in China and who refused to be laid-off for such a long time, now accepted the reform packages? It has, of course, been dependent on the development of, and reforms to, the social security system and increased government expenditures on unemployment insurance. But it also depends on the development of the nonstate sectors and the $\mathrm{J}_{\mathrm{t}}$, because that determines the opportunity costs of accepting the lay-off. The behavioural model of a state employee is written as following

$\mathrm{w}^{\mathrm{n}}(\mathrm{J}) \geq \mathrm{W}^{\mathrm{s}}\left(\mathrm{J}_{\mathrm{\tau}}\right)$

$\mathrm{w}^{\mathrm{n}}\left(\mathrm{J}_{\mathrm{r}}\right)=$ (if being laid off from the SOEs and going to the private sector)

money and non-money wage income from private undertakings $\left(J_{t}\right)$

+ social security income

- suffering from higher working efforts

- suffering from discrimination against the private sectors $\left(\mathrm{J}_{\mathrm{t}}\right)$

- risk premium of job uncertainty in private sectors

+ what a state employee can keep from the SOEs (housing, pension program and so on)

- losses in period of unemployment $\left(J_{t}\right)$

+ unemployment compensations from the government.

$\mathrm{w}^{s}\left(\mathrm{~J}_{\mathrm{t}}\right)=$ (if staying with SOEs)

money and non-money wage income from SOEs $\left(\mathrm{J}_{t}\right)$

+ income in forms of free housing, pension, medical care and so on

- losses because of the delay of wage payment or any payment from the

financially troubled SOEs $\left(\mathrm{J}_{\mathrm{t}}\right)$

+ the pleasure of less working efforts

+ satisfaction from the social status of being a state employee $\left(J_{t}\right)$.

Some of the factors of inequality are hard to measure quantitatively and make any monetary equivalent (such as suffering, pleasure or satisfaction), but they still play a role in the decision-making process. The various possible directions of correlation between the independent variables of the inequality and the $J_{t}$ should also be noted. For example, the higher the $J_{t}$, the less possible it is for an SOE to delay its payment to its workers because SOEs may still be in a monopolistic position. But for some regions that have lagged behind, the higher the $J_{t}$, the more probable the delay might be because in such a region more SOEs may suffer from financial difficulties. The issue is worth a great deal of further study, both theoretically and empirically.

\section{The possibility of a reversed course or crisis}

So far we have presented a relatively rosy picture of economic transition. As long as the non-state sectors grow, the conditions for reforming the state sector will improve and the institutional transition will be achieved in the long run, no matter how big the state sector or how long the transition process takes. 


\section{The dynamics of transition in China}

But where is the problem? In reality, reforms are faced with tremendous difficulties and people always worry about the possibility that the reforms may stop and the transition process may be reversed and then, as the result, economic growth may stop too. So where are the risks?

The key problem which has not been captured in the above model is the fact that the state sector may use its state power to control income redistribution and the allocation of resources, and consequently, slow down the change of $J_{t}$.

\section{Subsidies to SOES}

What is missing in the simplified model above is income redistribution. The state sector may have a lower growth rate, but it may still be able to rely on government power to control the distribution and resource allocation in order to subsidise SOEs. In China, the government not only has taxation power but has also kept the monopoly of state banks and state financial institutions in the financial sectors. Therefore, redistribution and subsidies take place in various forms such as

- fiscal subsidies - this kind of subsidy has been minor since the mid 1980s when the government shifted most of its fiscal responsibilities (equity

\section{Box 3.1 Gradual reform since 1978}

\section{Date}

1978-79

1979-10.84

$10.1984-10.87$

$10.1987-06.89$

$06.1989-91$

1992

10.1992

1994

1997

1998

10.1999

\section{Reform}

Planned economy using the law of market exchange value Planned economy supplemented with some market elements The planned commodity economy State regulating the market and market regulating enterprises Organic integration of planned economy and market regulations Shareholding system and security market (started) can be used by socialism

Socialist market economy

Corporatisation of SOEs and reform of property rights

Developing the state sector together with all other kinds of ownership. Improving large SOEs while letting small ones go to the market

Constituional Amendment. Private ownership should be equally promoted and protected

SOEs withdrawing from competitive industries. Diversification of ownership of corporate and mixed ownership. Executive stock options for SOES

Source: Central Committee of CCP, 1985. "Ten policies of the CCP Central Committee and the State Council for the further invigoration of the rural economy', in The Agricultural Yearbook of China, China Statistical Publishing House, Beijing:1-3. 


\section{Dilemmas of China's growth in the Twenty-First Century}

investment and subsidies) to the state banks. But recently this kind of subsidy has risen as the government has started to use a debt-equity swap program to reduce the non-performing loan burdens on SOEs

- non-performing loans between the SOEs and the state banks-this may also be called quasi-government debt

- non-performing foreign debts owed by the SOEs directly, or by the state financial institutions or by some government agencies that borrow in international market for the state sector.

- part of the funds raised from the security market for SOEs-it was officially claimed that one of the main roles of the current stock markets is to raise funds for SOEs that continue to be controlled by the government, as it holds unchangeable majority shares. The fact that most state-controlled companies listed on the stock market have since turned out to be loss-making indicates that a great deal of funds raised from the market are a form of public subsidy for the SOEs.

\section{Non-state sector as the source of subsidy to the state sector}

If the subsidy is not only the nominal one (taken back by inflation, for instance), it must come from somewhere in the economy. In a two-sector model, the subsidy to the state sector must come from the non-state sector. In this model the government is in the state sector. Even if we take the government as a third party, it still only channels the transfer between the two sectors.

To understand this, it is important to keep in mind the equality issue. If the non-state sector could get bank loans or foreign loans equally and could have an equally high non-performing loan ratio, or, if the non-state sector could go to the stock market to raise funds proportional to its contribution to GDP with equality, then there would be no real subsidy. It would be only equivalent to certain level of inflation in such a model. But, at least in China, equality is not the case. The most serious distortion of resource allocation is that the non-state sector, which contributes more than 70 per cent of output, uses less than 30 per cent of bank credits (Table 3.1). The most serious policy mistake in the past 20 years of reform has been the lack of development of the non-state financial institutions which would more adequately have served the growth of the non-state sector.

It is such subsidies that create the risk that the transition (indicated by a decreasing $J_{i}$ ) may be stopped or reversed. This can be seen when we bring such a redistribution factor into the model.

Let $\mathrm{D}$ stand for a form of taxation on the non-state sector which includes formal taxes and various levies, such as fees and contributions, bank deposits which would become non-performing loans, and public investment in the state 


\section{The dynamics of transition in China}

controlled companies listed in the stock market. $\Sigma D_{T}$ then stands for the comprehensive taxation on non-state sectors and $d$ for the comprehensive tax rate on non-state sector. We then have

$$
d=\frac{\sum D_{i}}{N}
$$

The $d$ actually indicates the total transfer from the non-state sector to the state sector, or the total subsidies that the SOEs receive. Therefore, we can call it the subsidy-transfer rate between the two sectors.

We then have Equation (3.2)

$$
J_{t}=\frac{S_{0}\left(1+g^{s}\right)^{t}}{N_{0}\left(1+g^{n}-d\right)^{t}}
$$

Equation (3.2) is actually no longer an output function of J but is a resource allocation function of $\mathrm{J}$, which describes the economic structure in terms of income redistribution and resource allocation between the two sectors. The existence of $d$ makes it possible that $\left(1+\mathrm{g}^{\mathrm{s}}\right)>\left(1+\mathrm{g}^{\mathrm{n}}-d\right)$, if $d>0$ and $d>\mathrm{g}^{\mathrm{n}}-\mathrm{g}^{\mathrm{s}}$.

Without doubt, the growth rates will be affected by the resource allocation. That is

$$
g_{t}^{n}(d)=f\left(d_{t}, d_{t-1}, d_{t-2} \ldots \ldots\right)
$$

As long as $d>0$, the growth rate of the non-state sector will slow down to a certain extent. If the $d$ is big enough, we may have $\mathrm{g}^{\mathrm{n}}(\mathrm{d})<\mathrm{g}^{\mathrm{s}}$, although we always have $\mathrm{g}^{\mathrm{s}}<\mathrm{g}^{\mathrm{n}}$ as the fundamental presumption of reform. We then have

$$
J_{t}=J_{0} \frac{\left(1+g^{s}\right)^{t}}{\left[1+g^{n}(d)\right]^{t}} \underset{t \rightarrow \infty}{\longrightarrow} \infty
$$

That is, the $J_{t}$ will be reversed, if not exploded. We call the situation described by (3.3) the possibility of reversal of the transition.

\section{Table 3.1 Economic structure of China, 1997-98 (per cent of total)}

\begin{tabular}{lcc}
\hline & State sector & Non-state sector \\
GDP & 37.8 & 62.2 \\
Industrial value-added & 26.47 & 73.53 \\
Investment & 54.1 & 45.9 \\
Bank credit & 68.2 & 31.8 \\
Export & 52.7 & 47.3 \\
Total increase in employment & -101.52 & 201.52 \\
\hline
\end{tabular}

Note: Some figures are data of 1997.

Source: State Statistical Bureau of China (SSB), 1999. China Statistical Yearbook, China Statistical Publishing House, Beijing (in Chinese). 


\section{Dilemmas of China's growth in the Twenty-First Century}

\section{Controlling $d:$ the real reason for SOE reform}

We have discussed the possibility of not reforming SOEs under the fundamental presumption of reform, that is $\mathrm{g}^{s}<\mathrm{g}^{\mathrm{n}}$. Having introduced $d$, that is, the taxation on the non-state sector and subsidies to the state sector, we see why we have to reform the state sector. It is necessary in order to prevent $d$ from becoming big in the real life of political economy. If the old sector could pass away naturally due to less efficiency, transition would be much less painful because it is possible to simply wait without reforming. But those people with a vested interest in the old system may use their political influence to resist the process of passing away, by taking subsidies from other sectors and stopping or even reversing the process of transition. People will have to reform the old sector with additional costs of reform, simply because others have exerted their efforts to survive.

The crucial point here is the size of $d$. The non-state sector may stop growing totally if $d$ gets too big, that is, if the economic surplus for growth of the non-state sector is taxed away. In any circumstances, the size of $d$ actually captures all possible factors that may cause the crisis and reversal of the transition. Therefore, the issue as to whether or not transition can continue and economic growth be sustained from the point of view of institutional change, boils down to the question of whether $d$ can be controlled without an explosion.

There are many reform policies that suggest ways to prevent $d$ from getting too big, so we shall avoid discussing them again here.

\section{A comparison of different approaches to transition}

The size of $d$ may be determined by the following factors

- the size of the state sector in the relation to the non-state sector at the initial stage and any particular time afterward: the bigger the state sector, the bigger the $d$ may be

- the financial situation of the state sector-the less efficient and less profitable (the two are not the same) the state sector as a whole, the bigger the $d$ may be. Historical experience justified by theoretical logic, shows that the longer the state economy exists, the worse its financial situation and the lower its profitability.

We can now compare the approaches to transition in different countries. In Russia, for instance, the almost entire domination of the state sector and a 70-year history of a planned economy left it with no choice but mass privatisation at the very beginning of transition. Otherwise the private sector would not grow because any economic surplus they received might immediately be taxed away (by inflation at least). In China, the relatively small size of the state industries (in terms of employment) at the initial stage of transition has made it possible to postpone the 
The dynamics of transition in China

\begin{tabular}{lccc}
\hline Table 3.2 & \multicolumn{2}{c}{$\begin{array}{c}\text { Comprehensive public-sector liability as a measure of } \\
\text { overall financial risk in the Chinese economy }\end{array}$} \\
\hline & 1997 & 1998 & $1998^{*}$ \\
Total NPL (\% of GDP) & 25.05 & 27.19 &.. \\
Government domestic debt (\% of GDP) & 7.32 & 8.78 &.. \\
Total foreign debt (\% of GDP) & 14.70 & 14.57 &.. \\
Comprehensive government liability ratio (\%) & 47.07 & 50.53 & 37.45 \\
Inflation RPI (\%) & 0.8 & -2.6 &.. \\
Total short-term foreign debt / GDP & 1.53 & 1.5 &.. \\
\hline
\end{tabular}

Notes: 1988 includes short-term foreign debt only; NPL is non-performing loans.

Source: State Statistical Bureau of China (SSB), 1999. China Statistical Yearbook, China

Statistical Publishing House, Beijing (in Chinese).

reform of SOEs for quite a long time. The relatively better financial situation of the SOEs (due to a shorter history) have made the $d$ relatively small, and have even enabled the government to give non-state companies some tax reductions in their early stages of growth. A similar argument may also be applicable to some Eastern European economies.

\section{Measuring overall financial risks and preventing a crisis}

The Chinese government has kept tax revenue below 15 per cent as a proportion of GDP in most years since the late 1980s. Therefore, subsidy transfer mainly takes the form of various kinds of public or quasi-public debts, including government debt, non-performing bank loans and foreign debt borrowed by government or SOEs. All of these debts are transferred from the private sector or the general public (as individuals) to loss-making SOEs (as long as they are still operating).

Therefore, the approximate measurement of the $\Sigma D_{i}$ and $d$ is the sum of the three kinds of debts: government debt, non-performing loans and the foreign debts, and the ratio of this sum over GDP.

$\mathrm{CLP}=\underline{\mathrm{NPL}}+$ government domestic debt + total foreign debt GDP

We take a rough, but popular, estimation of the non-performing loans as 25 per cent of total bank credits at the end of 1998. It was equivalent to about 27 per cent of GDP. At the same time, the government debt over GDP ratio was about nine per cent and the foreign debt over GDP ratio was about 14 per cent. Adding these up, the comprehensive public-sector liability (CPL), as it may be termed, is about 50 per cent over GDP (Table 3.2).

Compared to similar indicators of other economies (Table 3.3), China's overall 
Dilemmas of China's growth in the Twenty-First Century

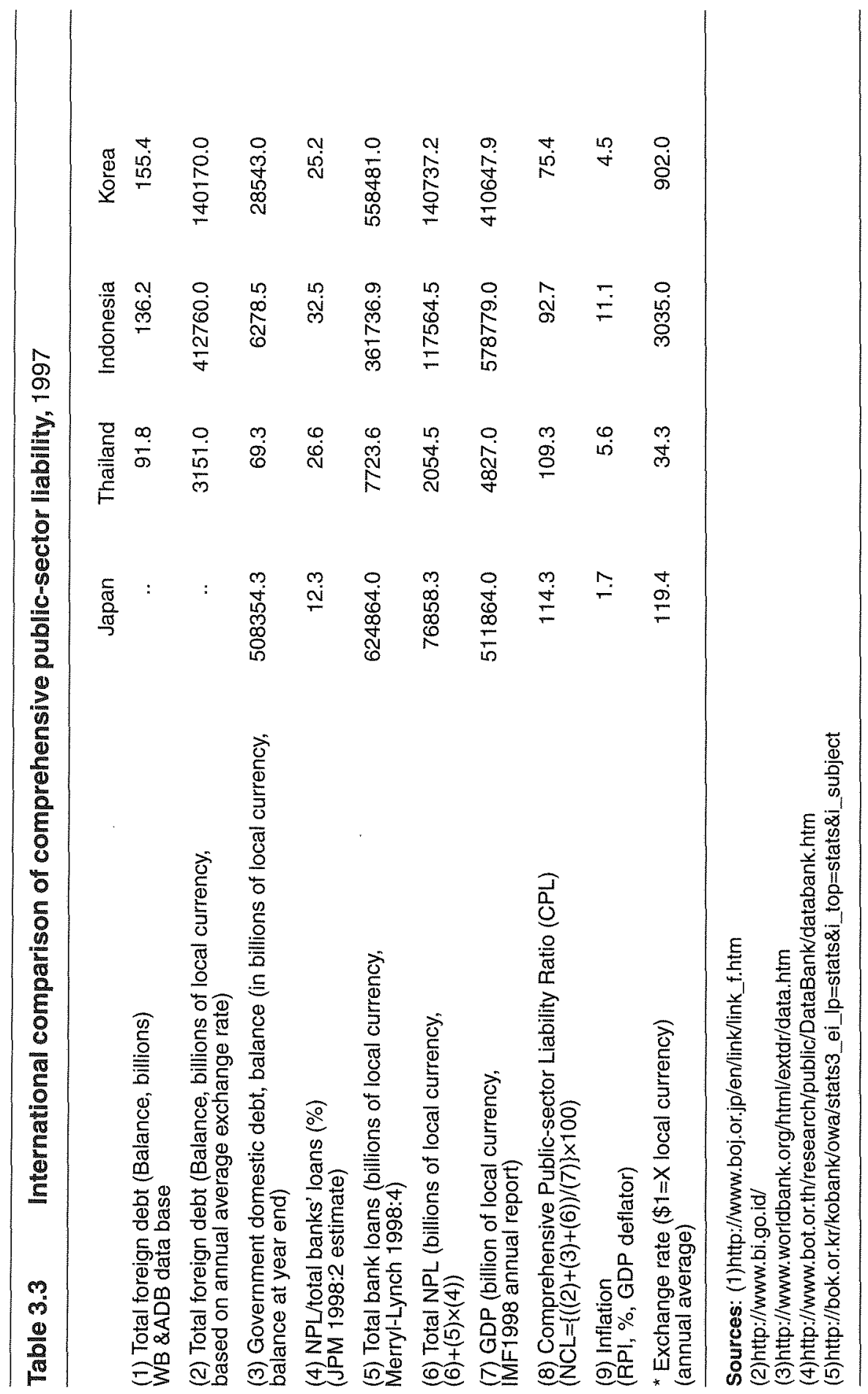




\section{Figure 3.2 Percentage change of non-state sector's contribution to the industrial output}

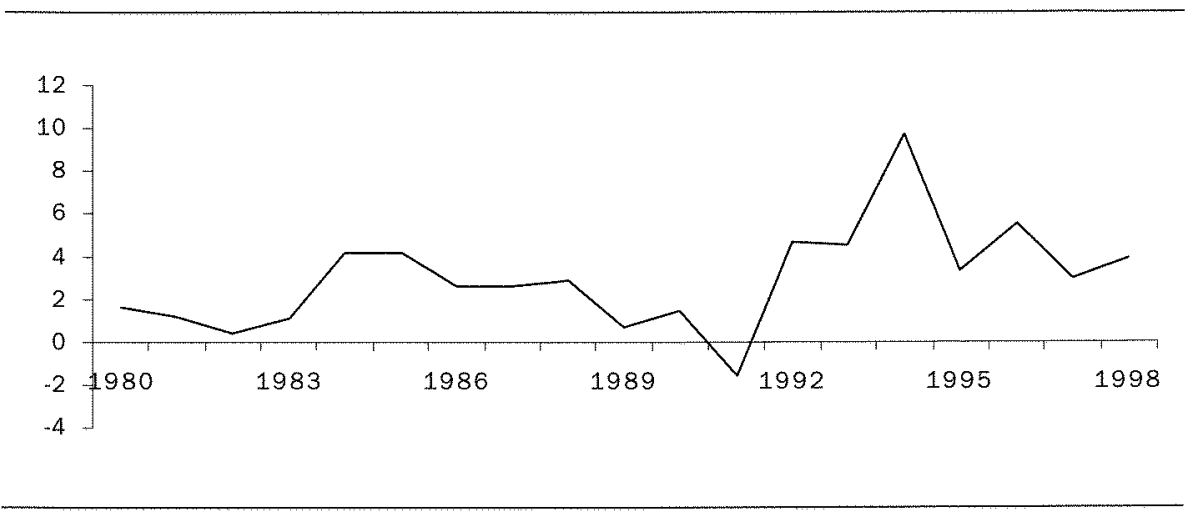

financial situation measured by CPL seems to be not as bad as the non-performing loans indicate, and it can be said that China is still not in danger of financial crisis within the foreseeable future.

In addition, looking at recent trends in economic structure, the $J$ is still steadily decreasing while the non-state sector keeps growing as the major contributor to output at a rate of one to two percentage points annually (Figure 3.2). This indicates the continuation of the process of transformation continues rather than its reversal.

\section{Concluding remarks}

This chapter tries to identify the causes of institutional transition and the factors that may lead to a crisis, stop, or even reversal at the transition process. It demonstrates that transition may gain its own momentum once it has started (fundamental assumption of the transition), but that there are possibilities that the process may not proceed successfully due to dislocation (subsidy-transfer).

While the theoretical analysis proves the possibility of reversal, the statistical evidence shows that economic transformation in China has been steadily going forward, as measured by the change of the ownership structure $(J)$. These statistics also show that transition will continue without the threat of crises or collapse in the foreseeable future. The future of China's institutional transition depends on the progress made preventing crises in the next stage of transition.

\section{Note}

1 By the state sector we mean the combination of the SOEs, state-banking system and the government. 